\title{
RISK MANAGEMENT OF MERGERS AND ACQUISITIONS WITH BORROWED CAPITAL IN THE ENERGY SECTOR
}

\author{
GALINA CHEBOTAREVA, PAVEL KHOMENKO \& MIKHAEL KHODOROVSKY \\ Academic Department of Banking and Investment Management, Ural Federal University, Russia.
}

\begin{abstract}
Under the conditions of macroeconomic instability and the difficulty of forecasting trends in the market development, a competitive recovery of the electric power business is possible only by attracting large capital investment. Mergers and acquisitions deals that make it possible to concentrate assets and to amalgamate the industry business are done through the leveraged buy-out (LBO) scheme. However, LBO deals are associated not only with the investor's risks, but also with the risks of the acquirers and vendors. The article presents the authors' model of risks formalization of LBO deals. It allows for consolidating the blocks of key project and financial indicators, parameters of a specific risk, and macroeconomic and sectoral factors. The developed model yields an indicative assessment of the degree of risk of LBO deals taking into account the industry specifics. A mechanism for determining the position of the creditor in the framework of LBO is proposed as a practical application of this model. The results of the study can be used by the management of energy companies, investors and analysts in making financial decisions.

Keywords: energy, Leveraged Buy-Out (LBO), Mergers and Acquisitions (M\&A) deals, risk management, risks, risks formalization.
\end{abstract}

\section{INTRODUCTION}

At the present time, the energy sector has a complex task of making a transition to a new higher level that provides for making the maximum contribution to dynamic socio-economic development. It involves a complex structural transformation: an increase in effectiveness of traditional and renewable energy use alongside with an increase in the rate of development and implementation of decentralized generation programs.

Mergers and acquisitions in the energy sector further the pooling of capital and the consolidation and stabilization of the market. However, such deals are not possible without debt financing and carry a high level of risk. Thus, there is a significant contradiction. On the one hand, M\&A deals contribute to the stability of the energy market [1]. On the other hand, the high level of overall risk [2] discourages investors as it increases the probability of a loss of the invested capital, especially in mega-deals.

The authors therefore see it as an important task to develop a model that makes it possible to limit the investor's risk in the deals.

The outcome of this study is the authors' model capable of formalizing the existing typical and specific risks in M\&A deals and of minimizing the level of investors risk limiting the volume of financing. The results have practical importance and are used for evaluating M\&A deals of energy companies.

\section{REVIEW OF RUSSIAN M\&A DEALS IN 2015}

Currently, the Russian M\&A market is characterized by decreased activity and the weakening confidence of national companies in the effectiveness of such transactions. This is primarily due to the high level of macroeconomic instability that is caused by a reduction in oil prices and the difficulty and cost of obtaining additional financing. 
The year 20015 showed the worst results in the Russian M\&A market over the past ten years. Total transactions decreased by $29 \%$ to $\$ 55.8$ billion. This was due to a decrease in transaction volumes by $19 \%$ and a decrease in the average transaction size by $11 \%$ [3] (Fig. 1).

At the same time, the value of transactions in the global M\&A market increased by $30 \%$ to $\$ 4.3$ trillion with a slight decrease of 3\% in the number of deals [3, 4] (Fig. 2).

Thus, the share of Russia in this market decreased to a minimum value of $1.3 \%$ compared with the average of $4.3 \%$ over the last decade. Cost analysis showed that 10 mega deals accounted for $45 \%$ of transactions in the Russian M\&A market. It is above the global level by $26 \%$ [3]. Industry analysis of the M\&A market showed that the energy industry continues to dominate in the Russian market. This is despite a decline in deal value from $\$ 33.1$ billion to $\$ 16.3$ billion and in total - from 73 to 58 . The structural characteristics of the Russian M\&A market by volume and number of deals by sector is presented in Figure 3.

The total list of the largest (incl. mega) M\&A deals of the Russian energy market is demonstrated in Table 1.

The most expensive outbound transaction of the global M\&A in 2015 was the acquisition by the Russian oil company Rosneft of a 49\% stake in vendor Essar Oil Ltd for \$2.4 million. A mega deal to acquire Russian assets by a foreign company took place between Silk Road Fund Co Ltd and Novatek.

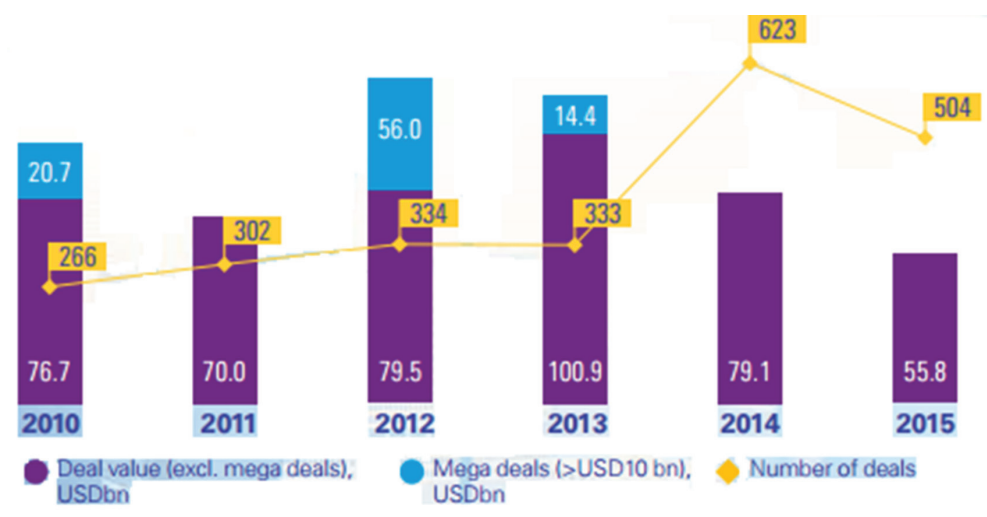

Figure 1: Russian M\&A deals (2010-2015) [3].

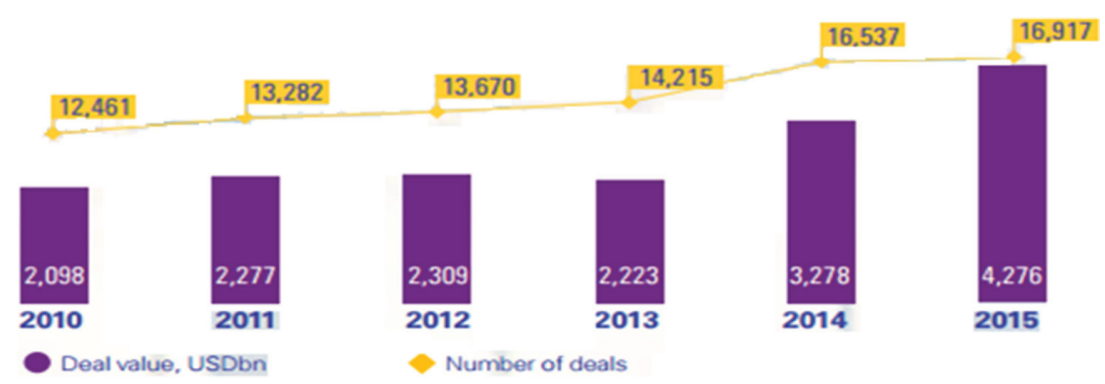

Figure 2: Global M\&A deals (2010-2015) [3]. 

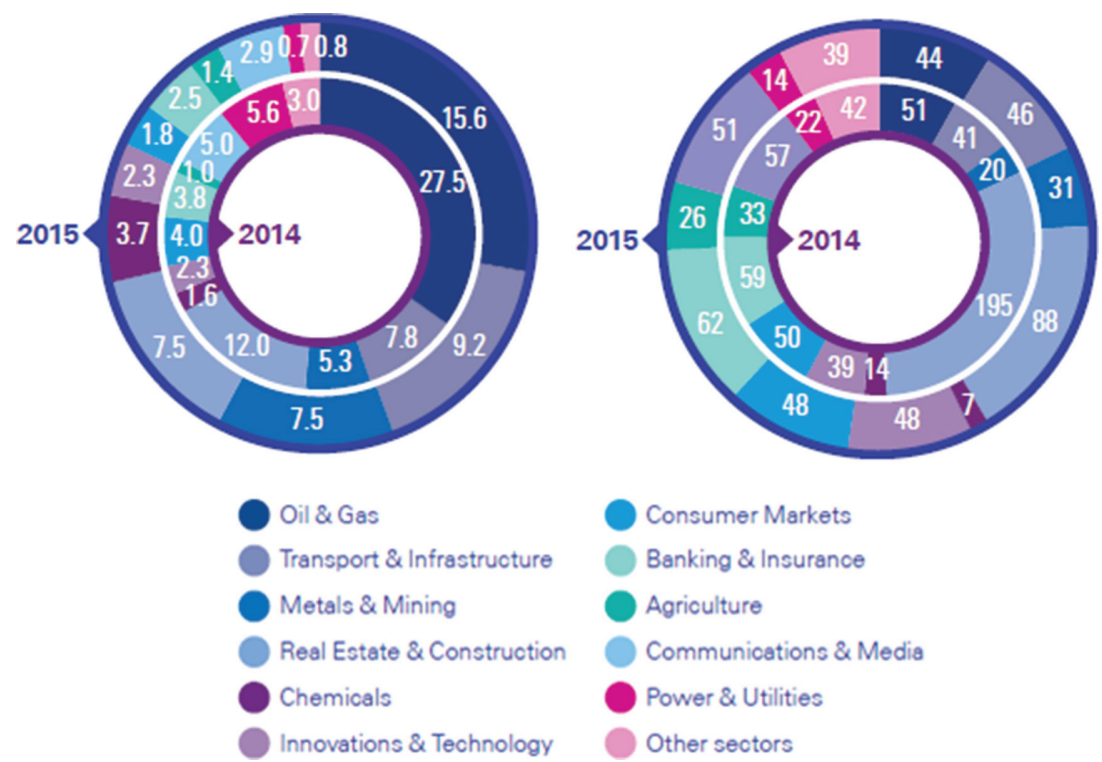

Figure 3: Russia M\&A value and volume by sector (2014 \& 2015) [4].

Table 1: M \& A deals in the energy sector (2015).

\begin{tabular}{|c|c|c|c|c|}
\hline Target & Acquirer & Vendor & $\%$ acquired & $\begin{array}{l}\text { Value, } \\
\text { USDm }\end{array}$ \\
\hline Essar Oil Ltd & Rosneft Oil Company & Essar & $49.0 \%$ & 2,400 \\
\hline $\begin{array}{l}\text { E.On E \& } \\
\text { P Norge }\end{array}$ & $\begin{array}{l}\text { DEA Deutsche Erdoel AG } \\
\text { (DEA) }\end{array}$ & E.On & $100.0 \%$ & 1,600 \\
\hline Yamal LNG & Silk Road Fund Co Ltd & Novatek & $9,9 \%$ & 1,400 \\
\hline SIBUR Holding & $\begin{array}{l}\text { China Petrochemical } \\
\text { Corporation (Sinopec } \\
\text { Group }\end{array}$ & $\begin{array}{l}\text { Leonid Mikhelson; } \\
\text { Kirill Shamalov; } \\
\text { Gennady Timchenko; } \\
\text { former and current } \\
\text { managers }\end{array}$ & $10,0 \%$ & 1,340 \\
\hline Vankorneft & ONGC Videsh Limited & Rosneft Oil Company & $15,0 \%$ & 1,300 \\
\hline RussNeft NK & Glencore plc & Mikhail Gutseriev & $49,0 \%$ & 900 \\
\hline Sulzer Ltd & Renova Group & Minority Shareholders & $29.5 \%$ & 1,032 \\
\hline Wish & DST Global & $\mathrm{n} / \mathrm{d}$ & $16,7 \%$ & 500 \\
\hline ANI & DST Global; Tiger Global & $\mathrm{n} / \mathrm{d}$ & $16,7 \%$ & 400 \\
\hline Technologies & Management; Falcon Edge & & & \\
\hline Pvt Ltd & $\begin{array}{l}\text { Capital LP; Softbank Corp; } \\
\text { GIC Pte Ltd; Accel Part- } \\
\text { ners; Rahul Mehta; Yuri } \\
\text { Milner; Steadview Capital } \\
\text { Management HK Ltd }\end{array}$ & & & \\
\hline
\end{tabular}




\section{RISK CHARACTERISTICS OF M\&A DEALS WITH LEVERAGED BUY-OUT (LBO) IN THE ENERGY SECTOR}

M\&A deals implemented on the basis of the LBO financing principles in the energy sector are accompanied by a significant number of risks. There are adverse influences of these risks on the company's financial standing. It contributes to a higher probability of default.

Transactions in the sphere of energy are characterized by an infinite number of risks. They are considered by the authors in the several papers [5-7].

Most risks in M\&A deals [8] are based on the absence of the required synergistic effect, that is, a failure to reach the planned results of operations after consolidation. These risks apply to investment $(1,6)$, finance $(2-4,6)$, operating (5-6) and technical (6) business areas of the energy company. In addition, usually it is important to highlight a number of external hazards (7-8). In the framework of the studies, eight such risks were identified.

1. Revaluation of the acquired company;

2. Withdrawal of the assets of the consolidated company;

3. Decrease in the capitalization of the consolidated company (compared to the total capitalization of the two companies);

4. Risk of a reduction in the profits of the consolidated company;

5. Infrastructure risks: lower effectiveness of the transaction as a result of administrative errors in the integration:

a. Loss of key employees,

b. Deterioration of the corporate culture.

6. Industry-specific risks affect all areas of the company [9]. In particular, they can be caused by the emergence of technological changes in the industry [9];

7. Market risks involve additional losses due to the volatility of the global feedstock market and financial markets;

8. Political risks: emergence of a 'foreign policy setback' for the implementation of the deal by direct or indirect prohibition.

The distribution of risks along the curve of the M\&A deal life cycle depending on the volume of attracted capital is presented in Figure 4.

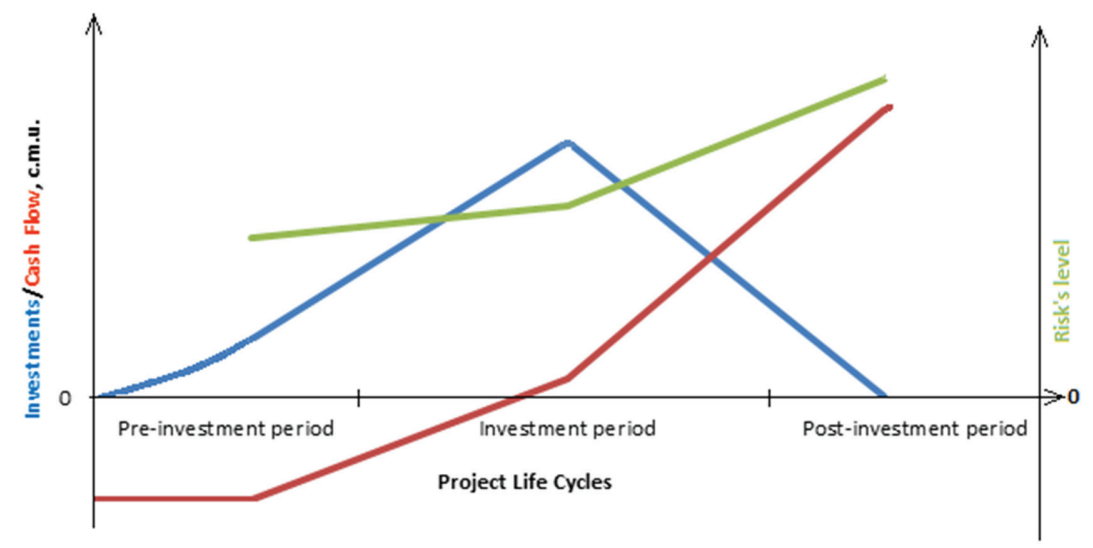

Figure 4: Distribution of risks by M\&A life cycles. 
It is important to note that for the acquirer in the sphere of energy business there is virtually no risk to business reputation of the vendor in this deal. This is primarily due to the capital intensity and inertia of the industry, and the practical impossibility of the emergence of new major players on the global energy market.

Taken together, these risks lead to the deterioration of the general financial condition of the acquiring company. Use of borrowed capital contributes to the occurrence of credit risk.

Prevention of the possibility of a default of the consolidated company requires prior forecasting of its condition. It must be based on the analysis of potential risks and calculation of the optimum ratio in investment terms: distribution of shares in the deal, its price and timing.

\section{METHODICAL APPROACH TO RISKS FORMALIZATION OF M\&A DEALS WITH LBO FOR AN ENERGY COMPANY}

A significant stage in the risk modeling of the LBO deals is the formalization of key risk factors that define financial sustainability of the transaction.

\subsection{Overview of the existing approaches}

There is a sufficient number of widespread concepts of the modeling and selection of risks. The most popular of these include:

- Microeconomic approach - based on the hypothesis of the impact of the individual quantitative and qualitative deal characteristics and its participants on risk. Under this approach, special attention is paid to specific factors of the transaction (corporative and capital risks, financial risks of the company-vendor, tax, human risks, the probability of the absence of a synergistic effect, etc.).

- Macroeconomic approach - based on the influence of government differences on the default of the LBO deals. The approach is widespread in contemporary research. In the articles $[10,11]$ the authors show that such factors as the size of the capital market, the current development of legislation have a significant impact on the default risk of LBOs.

- Market approach - based on market prices of shares, bonds and derivative financial instruments for predicting the probability of LBOs default. The examples are the studies given in Refs. [12, 13]. The study [12] of credit spreads is based on the structural models of Merton. In Ref. [12], the authors investigated the dependence of CDS spreads on the activity in the LBO deals. As a result, it is concluded that the announcement of LBO deals leads to an increase in CDS spreads. The effectiveness of the market models application is shown in Ref. [13].

\subsection{Blocks of indicators to risk formalization for an energy company}

This paragraph presents the key risk factors grouped in four blocks.

1. Block of project-financial indicators determines the relationship between the LBO risk and the main financial parameters. The formation of this block is based on the project 
approach to LBO deals. It includes methodologically accepted indicators [14] shown in Table 2. The specificity of the LBO is demonstrated by the use of the Debt/EBITDA indicator for characterizing the debt load of the consolidated company.

2. Block of the specific risk indicators allows for assessing specific risks in M\&A (LBO) deals presented in Table 3.

3. Block of macroeconomic and industry indicators (Table 4) describe the impact of risks of the national economy and the state of the industry on the sustainability of LBO deals. Within this bock, in order to simplify the model, an integral index of national credit rating assigned by rating agencies only is used.

4. Block of financial stress indicators shows the potential impact of the specific risks of LBO deals on model stability including debt financing (Table 5).

Table 2: Key risks indicators of project-financial block.

\begin{tabular}{|c|c|c|}
\hline Risk source & Indicator & Description \\
\hline The risk to financial sustainability & DSCR & $\begin{array}{l}\text { Minimum DSCR throughout the forecast } \\
\text { period }\end{array}$ \\
\hline The risk of project debt load & DEBITDA & $\begin{array}{l}\text { Maximum Debt/EBITDA during the } \\
\text { whole period of the project forecasting }\end{array}$ \\
\hline Interest rate risk coverage & ISCR & $\begin{array}{l}\text { Minimum ISCR throughout the forecast } \\
\text { period }\end{array}$ \\
\hline Net present value & NPV & Net Present Value of the project \\
\hline Internal rate of return & IRR & $\begin{array}{l}\text { Internal rate of return characterizes the } \\
\text { discount rate }\end{array}$ \\
\hline Discounted payback period & DPP & \\
\hline $\begin{array}{l}\text { The share of equity funds in the } \\
\text { project }\end{array}$ & EQFN & $\begin{array}{l}\text { Share of the investment budget, funded by } \\
\text { the business owners. }\end{array}$ \\
\hline $\begin{array}{l}\text { The ratio of the loan amount and } \\
\text { the market value of the collateral }\end{array}$ & LTV & $\begin{array}{l}\text { The loan amount } \mathrm{LBO} / \text { market value } \\
\text { of shares offered as collateral packages } \\
\text { (assets) of companies }\end{array}$ \\
\hline
\end{tabular}

Table 3: Key specific risks indicators block.

\begin{tabular}{lll}
\hline Risk source & Indicator & Description \\
\hline $\begin{array}{l}\text { The type of } \\
\text { merger }\end{array}$ & $\begin{array}{l}\text { MERG1 } \\
\text { MERG2 }\end{array}$ & $\begin{array}{l}\text { It characterizes the type of merger, depending on the char- } \\
\text { acter (dummy-variable): MERG1 - horizontal, MERG2 - } \\
\text { vertical, MERG3 - other }\end{array}$ \\
$\begin{array}{ll}\text { Merger geog- } \\
\text { raphy }\end{array}$ & $\begin{array}{l}\text { MERG4 } \\
\text { MERG5 }\end{array}$ & $\begin{array}{l}\text { Enabled by means of a dummy-variable: MERG4 - region- } \\
\text { al, MERG5 - national, MERG6 - international }\end{array}$ \\
$\begin{array}{l}\text { Due Diligence } \\
\text { Implementer }\end{array}$ & MERG7 & $\begin{array}{l}\text { MERG8 } \\
\text { Diligence: MERG7 - international auditing/consulting com- } \\
\text { pany, MERG8 - other }\end{array}$ \\
\hline
\end{tabular}


Table 4: Block of key macroeconomic and industry indicators.

\begin{tabular}{|c|c|c|}
\hline Risk source & Indicator & Description \\
\hline State of industry & $\begin{array}{l}\text { SECEC1 } \\
\text { SECEC2 } \\
\text { SECEC3 }\end{array}$ & $\begin{array}{l}\text { It characterizes the current dynamics in the industry. Dum- } \\
\text { my variable: SECEC } 1 \text { - presence of growth forecasts in } \\
\text { the industry, SECEC } 2 \text { - stable branch, SECEC } 3 \text { - expected } \\
\text { downturn in the industry, the reduction of the market. }\end{array}$ \\
\hline $\begin{array}{l}\text { The level of the } \\
\text { national stock market }\end{array}$ & SECEC4 & Stock market capitalization/GDP \\
\hline Country risks & $\begin{array}{l}\text { SECEC5 } \\
\text { SECEC6 } \\
\text { SECEC7 }\end{array}$ & $\begin{array}{l}\text { Indicator level of country risk is defined as a dummy vari- } \\
\text { able national credit rating: } \\
\text { SECEC5 - The rating of BBB and above, SECEC6 - rating } \\
\text { from BB to BBB, SECEC7 - rated B and below. }\end{array}$ \\
\hline
\end{tabular}

Table 5: Block of key financial stress indicators.

\begin{tabular}{|c|c|c|}
\hline Risk source & Indicator & Description \\
\hline $\begin{array}{l}\text { The risk of not } \\
\text { achieving synergy }\end{array}$ & DSCRStr1 & $\begin{array}{l}\text { Stability of the model to achieve the unexpected of syner- } \\
\text { gies. It is without taking into account the effect of the } \\
\text { synergistic effect on cash flows. }\end{array}$ \\
\hline Tax risk & DSCRStr2 & $\begin{array}{l}\text { Effect of potential tax risks in the fulfillment of obligations } \\
\text { in the case of the ability to implement them. Defined as the } \\
\text { minimum DSCR model to adjust the cash flow implications } \\
\text { on tax risk (identified as a result of Due Diligence). }\end{array}$ \\
\hline $\begin{array}{l}\text { The risk of loss of } \\
\text { key employees }\end{array}$ & $\begin{array}{l}\text { DSCRStr3 } \\
\text { DSCRStr4 }\end{array}$ & $\begin{array}{l}\text { Probability and impact of key personnel to the company. } \\
\text { Dummy variables: DSCRStr } 3 \text { - probability of leaving is } \\
\text { low, DSCRStr } 4 \text { - high impact of key personnel }\end{array}$ \\
\hline $\begin{array}{l}\text { The risk of joint/ } \\
\text { corporate conflicts }\end{array}$ & $\begin{array}{l}\text { DSCRStr5 } \\
\text { DSCRStr6 }\end{array}$ & $\begin{array}{l}\text { Probability of joint conflict that could disrupt operations, } \\
\text { recognition of the transaction invalid. Dummy variables: } \\
\text { DSCRStr5 - high probability, DSCRStr6 - low probability. }\end{array}$ \\
\hline $\begin{array}{l}\text { Antitrust } \\
\text { (administrative) } \\
\text { risks }\end{array}$ & $\begin{array}{l}\text { STR1 } \\
\text { STR2 }\end{array}$ & $\begin{array}{l}\text { Dummy variable, which characterizes the degree of risk } \\
\text { associated with anti-monopoly legislation: STR1 - anti- } \\
\text { monopoly legislation violation risks are absent, or have } \\
\text { obtained all relevant permits from antitrust authorities, } \\
\text { STR2 - a high risk of violating antitrust laws. }\end{array}$ \\
\hline
\end{tabular}

\subsection{Integration model of key risks indicator}

Definition of the key risk factors is the basis for choosing the information and mathematical forms of relations between variable indicators. The most widely used forms are:

- Logit and probit-models (based on regression analysis);

- Methods of classification (cluster and discriminant analysis),

- Advanced information and cybernetic methods (neural networks, fuzzy sets, genetic algorithms, model based on Big Data). 
In the framework of this study we used the logit-model presented by eqn (1):

$$
P D=\frac{1}{1+e^{-\Sigma_{i} b_{i} X_{i}}},
$$

where $P D$ is the probability of an energy company's default in LBO deals; $b_{i}$ is the coefficient of $i$-th factor; $x_{i}$ is $i$-th indicator of the risk-factor model.

\subsubsection{Results of risk indicator formalization}

Due to the absence of sufficient statistic data, LBO business plans information, to solve the difficult problem of determining the factor coefficients the method of expert analysis was used.

The results of the coefficients evaluation are given in Table 6 .

According to the analysis the greatest impact on the results are produced by the indicators of debt service coverage ratio (DSCR) and the debt load on the project (DEBITDA). It includes the sensitivity of the coverage to financial factors and qualitative stress.

\section{METHODICAL APPROACH TO LIMITING THE INVESTOR MARKET SHARE IN M\&A DEALS WITH LBO IN THE ENERGY SECTOR}

This paragraph demonstrates a model for evaluation of LBO deals' risk. The main purpose of this model is to limit the risk born by the investors in the project.

Table 6: Coefficients of risks indicator formalization for the energy company.

\begin{tabular}{llllll}
\hline \multirow{2}{*}{ Indicator } & $\begin{array}{l}\text { Tendency and } \\
\text { strength of relation }\end{array}$ & $\begin{array}{l}\text { Coeffi- } \\
\text { cient }\end{array}$ & Indicator & $\begin{array}{l}\text { Tendency and } \\
\text { strength of relation }\end{array}$ & Coefficient \\
\hline DSCR & +++ & $-1,785$ & SECEC1 & +++ & $-0,713$ \\
DEBITDA & -- & 0,927 & SECEC2 & + & $-0,025$ \\
ISCR & + & $-0,852$ & SECEC3 & -- & 0,459 \\
NPV & + & $-0,006$ & SECEC4 & + & $-0,054$ \\
IRR & + & $-0,008$ & SECEC5 & ++ & $-0,619$ \\
DPP & - & 0,018 & SECEC6 & + & $-0,080$ \\
EQFN & ++ & $-0,237$ & SECEC7 & - & 0,107 \\
LTV & +++ & $-0,194$ & DSCRStr1 & +++ & $-1,284$ \\
MERG1 & + & $-0,085$ & DSCRStr2 & ++ & $-0,950$ \\
MERG2 & ++ & $-0,106$ & DSCRStr3 & + & $-0,302$ \\
MERG3 & - & 0,032 & DSCRStr4 & -- & 0,915 \\
MERG4 & - & 0,167 & DSCRStr5 & -- & 1,162 \\
MERG5 & + & $-0,082$ & DSCRStr6 & + & $-0,317$ \\
MERG6 & + & $-0,116$ & STR1 & + & 0,214 \\
MERG7 & ++ & $-0,615$ & STR2 & -- & $-0,850$ \\
MERG8 & - & 0,091 & & & \\
\hline
\end{tabular}




\subsection{Basic components of the model}

There are the several characteristics of LBO deals' risk [7]:

$P D$ - probability of default. A key indicator characterizing the LBO deal risk level and reflecting the potential probability of the investment project default.

$L G D$ - loss given default. Expected average relative losses to be incurred by the company in case of the LBO deal default. In the case of default this portion of the investment project cost will be lost irrecoverably. The reason for introducing this indicator is that in the event of an LBO deal default it may be realized in full or in part by means of sale, insurance and option claims, etc.

$E A D$ - exposure at default. This characterizes the absolute value of the LBO deal and is determined by the project's full actual or forecast capital, current and other costs.

\subsection{Estimation model of limiting investor market share in LBO deal}

If the LBO deal is implemented with the attraction of debt financing, it is the question of ensuring the stability of the investment organizations in terms of their participation in financing. It is so important because these projects are capital intensive and their implementation involves significant risks that could have a considerable impact on the capital and regulatory standards of these organizations.

The investor determines the risk level based on the maximum amount of the losses. It will lead to the disruption of operating activities by eqn (2):

$$
N C A P=C C A P-T C A P,
$$

where NCAP is the capital of the investor, the loss of which would not lead to insolvency; $C C A P$ is the current energy company capital; TCAP is the target capital to cover overall risk of the energy company.

The volume of the target capital is evaluated using the credit rating of the energy company. Each credit rating may be assigned with a certain level of default probability corresponding to it depending on the forecasting horizon. One of the variants of correspondence between the credit rating and default probability is presented in Table $7[5,6]$.

The following limitation is the EAD volume. In this study, it is the potential volume of obligations of the acquirer (at the time of default). Therefore, the total maximum amount of creditor participation in the LBO budget can be defined as the minimum of the quantities by eqn (3):

$$
\text { Volume of investments }=\min (N C A P ; E A D) \text {. }
$$

Table 7: Correspondence between the probability of default and credit rating.

\begin{tabular}{llll}
\hline Rating & $1-Y$ PD & $3-Y$ PD & $5-Y$ PD \\
\hline AAA & $0,008 \%$ & $0,03 \%$ & $0,1 \%$ \\
AA & $0,04 \%$ & $0,16 \%$ & $0,28 \%$ \\
A & $0,16 \%$ & $0,4 \%$ & $0,58 \%$ \\
BBB & $0,3 \%$ & $1,4 \%$ & $3 \%$ \\
BB & $1,15 \%$ & $8,6 \%$ & $15 \%$ \\
B & $5,8 \%$ & $15,4 \%$ & $32,6 \%$ \\
CCC or lower & $26,57 \%$ & $45,5 \%$ & $60 \%$ \\
\hline
\end{tabular}


Thus, the limiting market share of the investor can be determined by eqn (4):

$$
I M S=\frac{\min (N C A P ; E A D)}{B D G},
$$

where IMS is the market share of the investor in the LBO deal; $B D G$ is the total LBO budget.

\subsubsection{Additional components to investor limitation}

The limiting market share of the investor can be corrected additionally. It depends on the level of risk (determined by the PD) and LGD. For the purposes of further indication, these indicators were put together based on the level of expected losses (EL) in eqn (5):

$$
E L=P D \cdot L G D
$$

Table 8 shows the distribution of the EL values, depending on the risk level.

Based on the EL-level, it is proposed that additional correction $(\mathrm{K})$ to the LBO budget be implemented. The factor $\mathrm{K}$ allows for reducing the creditor market share in the deal with a high level of risk (Table 9).

The final outcome of this study is the summarized formula of the investor market share in the LBO deal. Equation (6) makes it possible to form a limit of the total borrowed capital in accordance with the deal risk level:

$$
I M S_{K}=\frac{\min (N C A P ; K \cdot E A D)}{B D G}
$$

where $I M S_{K}$ is the corrected value of IMS.

Table 8: EL-distribution by the probability of default (PD) and LGD.

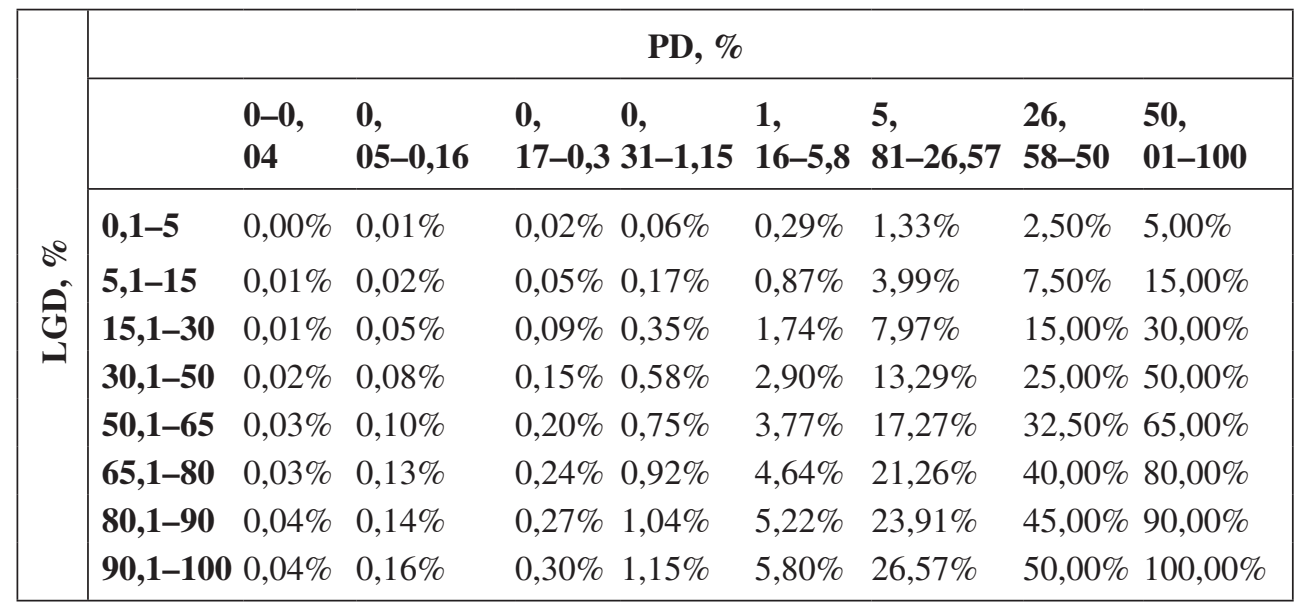

Table 9: Correspondence between the $K$-factor and $E L$-level.

\begin{tabular}{lllllllll}
\hline$E L$ & $0-0,05$ & $0,06-0,1$ & $0,11-0,15$ & $0,16-0,3$ & $0,31-0,7$ & $0,71-1,2$ & $1,21-2$ & $2,1-3,5$ \\
\hline $\mathrm{K}$ & 1 & 0,99 & 0,97 & 0,95 & 0,93 & 0,9 & 0,85 & 0,8 \\
EL & $3,51-5$ & $5,01-8$ & $8,01-10$ & $10,01-25$ & $25,01-32$ & $32,01-45$ & $45,01-75$ & $75,01-100$ \\
$\mathrm{~K}$ & 0,75 & 0,65 & 0,5 & 0,35 & 0,1 & 0,005 & 0,0001 & 0 \\
\hline
\end{tabular}




\section{CONCLUSIONS}

The important part in the risk assessment process is building a model that allows for a quantitative evaluation. At the next stages this model can be used for the purposes of measuring the risk, forming the cost and target capital yield, assessment of investors' sustainability [15].

This problem solution is proposed for the evaluation of the probability of default as an internationally accepted measure of credit risk. The introduced model includes the evaluation of deal-financial indicators, specific risks indicators, macroeconomic and sectoral indicators of financial stress. As the result of the integration of these indicators into the model, it is possible to obtain the overall risk indicator. In practice, it means the creditor market share in the total budget of the deal. A mechanism of reducing of the debt participation of a creditor in deals with a high level of risk.

The main directions of further research are:

- Formation of a statistical sample size on real LBOs. It will make it possible to replace expert opinion with a statistically reasonable measure of the coefficients.

- Explanation of the sensitivity level to calculate the EL-intervals to improve the quality of risk and $K$-factor.

- Econometric explanation of the EL-matrix.

- Development of a pricing model of the borrowed funds (taking into account the level of LBO risk).

\section{ACKNOWLEDGEMENTS}

The work was supported by Act 211 of the Government of the Russian Federation, contract No 02.A03.21.0006.

\section{REFERENCES}

[1] Mokhov, V. \& Stakhanov, K., Modelling the innovation activity of an enterprise. Bulletin of the South Ural State University. Series Mathematical Modelling, Programming \& Computer Software, 9(2), pp. 130-134, 2016.

[2] Domnikov, A., Chebotareva, G. \& Domnikova, L., Economic and technological priorities of competitive development of russian systems of energy cogeneration sources. International Journal of Design \& Nature and Ecodynamics, WIT Press, 11(4), pp. 610-619, 2016.

[3] Russia M\&A review 2015. Analytical Study; KPMG, 2016, available at https://assets. kpmg.com/content/dam/kpmg/pdf/2016/03/ru-en-russian-ma-review-2015.pdf (accessed 10 November 2016).

[4] Monthly M\&A Insider. A Mergermarket Report on Global M\&A Activity; Mergermarket, 2009, available at http://www.mergermarket.com/PDF/M\&A_Insider_Dec_09.pdf (accessed 10 November 2016).

[5] Chebotareva, G. \& Domnikov, A., Assessment of competitiveness of power generating companies through a risk based approach: a case study of developing economies. International Journal of Energy Production and Management: The Quest for Sustainable Energy: WIT Press, 1(4), pp. 322-331, 2016. https://doi.org/10.2495/EQ-1-4-322-331

[6] Domnikov, A., Khomenko, P. \& Chebotareva, G., A risk-oriented approach to capital management at a power generation company in Russia. WIT Transactions on Ecology and the Environment, 186, pp. 13-24, 2014.

https://doi.org/10.2495/esus140021 
[7] Domnikov, A., Chebotareva, G., Khomenko, P. \& Khodorovsky, M., Risk-oriented approach to long-term sustainability management for oil and gas companies in the course of implementation of investment projects. WIT Transactions on Ecology and the Environment, 192, pp. 275-284, 2015.

https://doi.org/10.2495/eco150251

[8] Domnikov, A., Chebotareva, G. \& Khodorovsky, M., Development of risk management for power generating companies in developing countries. WIT Transactions on Ecology and the Environment, 193, pp. 859-870, 2015.

https://doi.org/10.2495/sdp150721

[9] Domnikov, A., Chebotareva, G. \& Khodorovsky, M., Evaluation of investor attractiveness of power-generating companies: special reference to the development risks of the electric power industry. WIT Transactions on Ecology and the Environment, 190, pp. 199-210, 2014. https://doi.org/10.2495/eq140211

[10] Sorland, B.F. \& Rudel, M.G.N., What drives financial distress risk and default rates of leveraged buyout targets? empirical evidence from European transactions. Norwegian School of Economics, 2015.

[11] Lang, M., Cremers, H. \& Hentze, R., Rating model for estimating the probability of default in LBO transactions. Frankfurt School - Working Paper Series, 136, 2010.

[12] Eisenthal, Y., Feldhütter, P. \& Vig, V., Leveraged buyouts and credit spreads. Columbia Business School, 16, p. 57, 2016.

[13] Groh, A.P., Baule, R. \& Gottschalg, O., Measuring idiosyncratic risks in leveraged buyout transactions. Quarterly Journal of Finance and Accounting, 47(4), pp. 15-23, 2008. https://doi.org/10.2139/ssrn.965684

[14] Morgunov, V.A., Simulation of the probability of default of investment projects. Corporate Finance, 10(1), pp. 23-45, 2016.

[15] Global oil and gas transactions review 2015. Analytical Study; EY Research, 2016, available at http://www.ey.com/GL/en/Industries/Oil-Gas/EY-global-oil-and-gastransactions-review-2015 (accessed 10 November 2016). 